21) A. Coupper, D.D. Eley, Discussion Faraday Soc., No.8, 172 (1950)

22) G. Rienäcker, B. Sarry, Z. anorg. chem., 257, 41 (1948)

23) R.A. Sowe, W.W. Russell, J. Am. Chem. Soc., 76, 319 (1954)

24) V.N. Ipatieff, B.B. Corson, I.D. Kurvatov, $J$. Phys. Chem., 43, 598. (1939)

25) S. Yamaguchi, T. Takeuchi, Kolloid. Z. 150, 69 (1957); J. Colloid Science, 12, 263 (1957); $Z$. anorg. allgem. chem., 294, 254 (1958); J. Phys. Chem., 61, 1023 (1957)

26) T. Takeuchi, F. Shibata, M. Sakaguchi, $Z$.
Phys. Chem. N.F., 14, 339 (1958)

27) T. Takeuchi, M. Sakaguchi, Bull. Chem. Soc. Japan, 30, 177 (1957)

28）T. Takeuchi，T. Okano，近日発表予定

29) G.C. Kucyznski, J. Metal, 185, 813 (1949); ibid., 187, 169 (1949)

30) P.B. Shallcross, Thesis, Brown University (1958).

31) H.E. Fansworth, R.F. Woodcock, "Advances in Catalysis and Related Subjects" Vol. 9, 123 (1957) ; H.E. Fansworth, I. Tuul, Phys. J. Chem. Solids, 9, 48, 57 (1958)

\title{
高压還元による高級アルコールの製造
}

\author{
宮川 善 —* \\ Production of Higher Fatty Alcohols by the Catalytic \\ Hydrogenation
}

\section{Zenichi Miyagawa}

\section{1. まえがき}

高級アルコールは合成洗剤, 各種界面活性剤, 可塑剤 などの原料として, その需要が急激に増大し, 生産実績 は表-1 のように, 特に還元アルコールマ特いて確実な

\begin{tabular}{|c|c|c|c|c|}
\hline \multirow[t]{2}{*}{ 脿-1 } & \multicolumn{3}{|c|}{$\begin{array}{l}\text { 高級アルコールの生産実績 } \\
\text { (単位 t ) }\end{array}$} & \multirow{2}{*}{$\begin{array}{l}\text { 伸びを示してい } \\
\text { る。 } \\
\text { 現在脂肪アルコ }\end{array}$} \\
\hline & 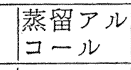 & 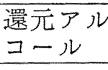 & 合 計 & \\
\hline 1950年 & 901 & 571 & 1,472 & \\
\hline 1951年 & 1,831 & 958 & 2,789 & 使 \\
\hline 1952年 & 2,357 & 1,186 & 3,543 & 法は，油脂または \\
\hline 1953年 & 3,739 & 1,634 & 5,373 & 胜 \\
\hline 1954年 & 3,807 & 1,698 & 5,505 & \\
\hline 1955年 & 4,136 & 2,122 & 6,258 & 金属ナトリウム還 \\
\hline 1956年 & 5,275 & 4,400 & 9,675 & 元, 油脂, 脂肪酸 \\
\hline 1957年 & 6,583 & 5,341 & 11,924 & \\
\hline 1958年 & 6,170 & 6,456 & 12,626 & \\
\hline \multicolumn{4}{|c|}{ （通産省化学統計調査室資料より） } & よびマッコウ鯨油 \\
\hline
\end{tabular}

Bouveault-Blanc 法の改良法 ${ }^{1)}$ の発明と, 今次大戦中の 高級アルコールの急激な需要増加により, 技術的にも大 進歩を示し, 設備が比較的簡易で低廉ですむことから, 一時はなやかな脚光を浴びたが，還元経費が割高につく ため，最近では高級飽和アルコールの製造は次第に高圧 還元法に変って来ているようである2。しかしながら最 近金属ナトリウムの製造についてもいろいろ技術的な改

* 花王石鹼株式会社（東京都中央区日本橋馬喰町） Kaō Soap Co., Ltd.
良が加兄られて和り，また金属ナトリウムの用途拡大に より大量生産によるコスト低下の期待される面もあり, かつまた水素化りチウムアルミニウム法ととると高度不 飽和アルコールの製造が可能であるので，この特色を生 かして今後の発展が期待される。

マッコウ鯨油のケン化蒸留法は製造コストは低廉であ るが, 生成アルコールの種類が限定されるため, 現在生 産過剩になやまされているが，製造各社和いて用途開 発の努力が払われているので，早晩解決をみるものと思 われる。

可塑剤や一部の界面活性剂原料として, 特飞直鎖アル コールを必要としない面には，オキソ法その他の合成ア ルコールが大量に生産, 利用されている。

最近 Ziegler 法による直鎖第一アルコールの製造 法 ${ }^{3)}{ }^{4)}$ が発表されているが，その経済性についてはなだ 明らかでない。

高圧還元法による高級アルコールの製造については, 既に小森・豊田 ${ }^{5)}$, 宮川 $\left.\right|^{6)}$ らの総説にくわしく述べられ て和り, それ以後飞発表された研究報告括よび特許の数 は比較的少ないが，ここではこれら総説との重複をでき るだけさけて，二，三の補足検討索加光てみたい。な和 最近の報文，特許でも新規性の少ないもの，または本論 を進める上にあまり重要でないと思われるるの訬略し た。

\section{2. 反応の経過}

油脂類の高圧還元の反応機構として $\mathrm{RCOOR}^{\prime}+\mathrm{H}_{2} \rightarrow \mathrm{RCH}(\mathrm{OH}) \mathrm{OR}^{\prime}$ 


\author{
$\rightarrow \mathrm{RCHO}+\mathrm{R}^{\prime} \mathrm{OH} \stackrel{\mathrm{H}_{2}}{\longrightarrow} \rightarrow \mathrm{RCH}_{2} \mathrm{OH}+\mathrm{R}^{\prime} \mathrm{OH}$ \\ (ただし RCOOR'はグリセリド，ロウ，またはエス \\ テル)
}

礼よりまず半アセタールまたはアルデヒドを生じ，これ がさらに還元されてアルコールになると考えられるが， 実験的には確認されていない。

反応の平衡は他の均一相系反応と同じであるが，ただ この場合には反応系の平衡組成はるっぱら水素圧力と反 応温度に支配される。な物原料の種類により，水皇たは 低級アルコールなぞの蒸気圧の高い副生成物を生ずる場 合は気相空間の影響を受ける。

Adkins ら`とよれば，下記の反応

$$
\begin{aligned}
& \mathrm{C}_{7} \mathrm{H}_{15} \mathrm{COOCH}_{2} \mathrm{C}_{7} \mathrm{H}_{15}+2 \mathrm{H}_{2} \\
& \rightleftharpoons 2 \mathrm{C}_{7} \mathrm{H}_{15} \mathrm{CH}_{2} \mathrm{OH}
\end{aligned}
$$

を $260^{\circ} \mathrm{C}$ で行なわしめた 場合の平衡反応率は，水素压 力 $140 \mathrm{psi}$ で $20 \%, 1200 \mathrm{psi}$ で 90\%, $4000 \mathrm{psi}$ で $99 \%$ であった。な皎，反応温度と平衡反応率と飞関する文献 壮見当らなかったが，発熱反応であることより，低温の 方が平衡反応率が高いと考光られ，実際にもとのような 傾向が恐められる。

反応速度に関しては Hougen $5^{8)}$ の考光に基づく化 学反応工学的取り扱いを経るのが一般的であり, 液相下 に特ける油脂の硬化乞の他二重結合に対する水素添加飞

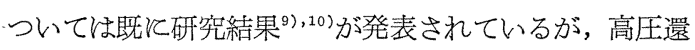
元による高級アルコールの製造についてはまだ公表され オデータはないようである。

油脂の高圧還元汇括いては, 反応系は固体触媒, 液体 油脂和よび気体水素よりなり, 反応は固体表面でのみ行 なわれる。還元反応の進行の過程を列記すれば，

（1）気体の水素が液体油脂溶解する。

（2）油脂飞溶解した水素以触媒表面に到達し, 同時 そ油脂子触媒表面に到達する。

（3）触媒表面に到達した油脂呿よび水素は触媒表面 に吸着される。

（4）触媒表面に吸着された油脂拉よび水素は触媒表 面で化学反応を行ない高級アルコールを生成す る。

（5）生成した高級アルヒールは触媒表面より脱着し，

(6) 液相へ移動する。

上記の過程中で最子遅い段階が律速段階として全体の 反応速度が定められる。工業的には (3), (4) または (5) の過程が律速段階として反応が行なわれるのが好まし い。(1)，(2) または（6）が律速段階（物質移動律速） であれば，かくはんを充分行なうことにより反応速度が 大きくなる場合が多い。このことはオートクレーブを用 いた実験でしばしば経験するところで，工業的の装置に 招いてもこれに類した事笑が珰められる。

反応筒に油脂物よび触媒を軽続的に圧入し, 別と水素
ガスを循環ポンプルより送入して, 反応生成アルコール のみを反応筒外飞留出せしめる蒸留式プラント ${ }^{11}$ 亿和い ては, 水素循環量の増大に伴い, ある程度まで留出アル コール量すなわち見掛けの反応速度は増大する。水素循 環量の増大に従いアルコール留出量の増大するような条 件下に括いては, 実際の反応速度より留出速度が遅く, 一種の物質移動律速となっているものと見なされる。こ のような状態は触媒の利用率の上からるまた装置能力の 点からも好ましくないが，ただ一概に反応律速状態即工 業的最適条件とは限らないので, 反応生成物の品質など をる考虑して条件を定めるべきであるう。

このような取り扱いはプラント設計に和いて必要・立 分条件を満し, 予定ど括りの能力を有する設備を得よう とする反応工学の一部門を占めるものである。

\section{3. 触媒について}

高圧還元による高級アルコールの製造には, 現在主と して銅クロマイト系触媒が用いられているが, 金属七ッ ケンが使用される場合もある。

\section{1. 銅クロマイト系触媒}

銅クロマイト触媒は Adkins ら ${ }^{12), 13)}$ の創製になるも ので，カルボキシル基の水酸基への還元触媒としてきわ めて有効で，画期的発明と称すべきであろう。

銓クロマイト触媒の製法には本質的な進歩はないが, 高活性のものが得られるよう次第飞改良 ${ }^{14), 15), 16)}$ されて きて顿り, Adkins $ら^{17)}$ は Riener ${ }^{16)}$ の方法を推奚して いる。

銅クロマイト触媒製造の主反応は次式のように考兄ら れている。

$$
\begin{aligned}
& 2 \mathrm{Cu}\left(\mathrm{NO}_{3}\right)_{2}+\mathrm{Na}_{2} \mathrm{Cr}_{2} \mathrm{O}_{7}+4 \mathrm{NH}_{4} \mathrm{OH} \\
& 2 \mathrm{CuNH}_{4} \mathrm{OHCrO}_{4}+2 \mathrm{NaNO}_{3}+2 \mathrm{NH}_{4} \mathrm{NO}_{3}+\mathrm{H}_{2} \mathrm{O} \\
& \mathrm{CuO} \cdot \mathrm{CuCr}_{2} \mathrm{O}_{4}+\mathrm{N}_{2}+5 \mathrm{H}_{2} \mathrm{O}
\end{aligned}
$$

銅クロマイト触媒々製造条件のわずかな変動により触 媒活性は微妙な変化をするため, 常に製造ロットごとに その活性を評価して招く必要がある。Adkins ら ネーニッケルの存在下に繁留して触媒毒を除いたラウリ ン酸メチルまたはエチル 0.1 モルに試験すべき触媒 $5 \mathrm{~g}$ を加光, さらにメタノールをたはエタノールを加えて $100 \mathrm{ml}$ とし, 水素圧 $5000 \sim 6000 \mathrm{psi}$, 温度 $175^{\circ} \mathrm{C}$ で 3 hr 還元してアルコール変換率 $50 \%$ 以上のるのを良触 媒としている。

銅クロマイト触腜の寿命については, Church ら ${ }^{18)}$ の ラウリン酸メチルの高圧還元実験結果ではかなり永く, 繰り返し使用が可能である。しかしながら実際の製造に 括いては繰り返し使用していると, 酸化銅と第二銅ク口

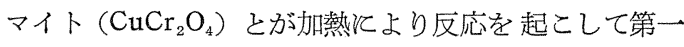
銅クロマイト $\left(\mathrm{Cu}_{2} \mathrm{Cr}_{2} \mathrm{O}_{4}\right)$ を生じたり, 酸化銅が水素に より還元されて金属銅となって次第に活性を失なう。 
繰返し使用して活性の低下した触媒は空気中で焙焼す ることにより再活性化されるといわれ，Stroupe ${ }^{19)}$ らの X線を用いた研究結果によれば, 再活性化は次式で示さ れる。

$$
\begin{aligned}
& \mathrm{CuO}+\mathrm{CuCr}_{2} \mathrm{O}_{4} \stackrel{\text { 使用 }}{\rightarrow} \mathrm{Cu}+\mathrm{Cu}_{2} \mathrm{Cr}_{2} \mathrm{O}_{4} \\
& \begin{aligned}
\text { 酸素処理 } & \downarrow \text { 空気中焙烍 }
\end{aligned} \\
& \left(\mathrm{CuO}+\mathrm{CuCr}_{2} \mathrm{O}_{4} \underset{600 \sim 700^{\circ} \mathrm{C}}{\stackrel{900^{\circ} \mathrm{C}}{\leftrightarrows}} \mathrm{Cu}_{2} \mathrm{Cr}_{2} \mathrm{O}_{4}+[\mathrm{O}]\right)
\end{aligned}
$$

実際にはこの方法による完全な再活性化は困難なようで ある。

天然油脂中怡触媒毒の存在する場合が多いが, Kane $ら^{20)}$ 《この問題飞関連して種々の油脂を銅クロマイト触 媒 (Co 添加) $5 \%$, 水素初圧 2500 psi（水素過剩率 175 \%), $325^{\circ} \mathrm{F}$ で $2 \mathrm{hr}$ 還元を行なったが, アルコール変 換率はヤシ油で 70\%, kooheri, kohum, mahua, white dumer fat では 45 70\%, pongam oil では 15\%, mangosa oil では 0\%であった。 mangosa oil の触媒 毒作用はヤシ油に 10\% 添加しただけでアルコール変換 率は 20\% 飞低下した。Kane らはこのような触媒毒作 用を示するのは油脂中に 2〜 5\% 含有されている不ケン 化物による8のと考光, これらの油脂をアルカリ処理後 エタノール抽出を行ない不ケン化物を除いたところアル コール変換率は向上したという。

一般の油脂は前処理により，アルコール変換率を向上 させることがでさるが，特殊の例として，Kane ら ${ }^{211} の$ neem oil そついての実験結果では，粗製油，精製油抒 よびそのメチルエステルのいずれからも高圧還元により 対応する高級アルコールを得ることができなかったが， ナトリウム還元法では三者とも90\%の反応率で高級ア ルコールが得られたと報じている。

銅クロマイト触媒は不飽和結合に対する水素添加能も あるので，すっぱら飽和アルコール製造に使用されてい る。この系統の触媒で不飽和アルコールをうるマは, 二 重結合飞対する保護作用のあるカドミウムなぞを併用す る必要がある。Lauer ら ${ }^{22)}$ は共沈により製したカドミ ウム添加銅クロマイト触媒 10\%を用い，エシシプト産綿 実油を水素圧 $300 \mathrm{~atm}, 350^{\circ} \mathrm{C}$ で $2 \mathrm{hr}$ 還元を行ない， 全アルコール収率 89\%, 不飽和アルコール 66\% (全ア ルコールに対し）を得ている。また Moreno ら ${ }^{23)}$ は銅 クロマイト触媒 $10 \%$ ，炭酸カドミウム $3.75 \%$ を併用 乙て水素圧 $200 \mathrm{~atm}, 265^{\circ} \mathrm{C}$ で 2 3 hr 還元を行ない， オレイン酸, sulfur olive oil, 㐨よびオリーブ油脂肪酸 から対応する不飽和アルコールを $92 \%$ の収率で得たと 報じている。

銅以外の金属のクロマイト系触媒については, 小㷊 ${ }^{24)}$ らの研究により, 覀鉛, カドミウム, コバルト, 鉄なぞ のクロマイト触媒が不飽和アルコールの製造に適してい
ることが見出されている。

高圧還元法による不飽和アルコールの製造については 多数の研究物よび特許があり, 半工業的に実施されたこ ともあるが，今日この方法による不飽和アルコールの製 造は行なわれていない。高压還元法では高度不飽和アル コールの製造が不可能であること，オレイルアルコール を主とした不飽和アルコールは現在マッコウ鯨油のケン 化蒸留法により容易にしか子きわめて低コストで製造さ れているため, オレイルアルコールの急激な需要増加の ない限り高圧還元による不飽和アルコール製造の工業化 害現は困難であらう。

\section{2. 金属セッケン触媒}

金属セッケンは銅クロマイト系触媒に比べ, 比較的性 能の安定したるのが得られやすい点と特徵があるようと 考学られる。使用範囲はほほぼ銅クロマイト系触媒と同じ で, 油脂, 脂肪酸括よびそのエステルから高級アルコー ルが得られるし，また金属七ッケンのみを還元しても対 応する高級アルコールとなる。

還元用触媒として用いられるのは銅セッケンが主で， そのほか亜鉛, 鉛, マンガン, コバルト、ニッケルなぞ の脂肪酸セッケンも単独にまたは併用して使われる

銅セッケンは脂肪酸のナトリウムまたはカリウム塩之: 水溶性の銅塩との複分解，または脂肪酸と炭酸銅をたは 酸化銅との直接反応により製造される。

銅セッケンは一般に $(\mathrm{RCOO})_{2} \mathrm{Cu}$ で示されるが，害 際には $\left[(\mathrm{RCOO})_{2} \mathrm{Cu}\right]_{2}$ の形で存在するといわれている。 空気中で $270 \sim 280^{\circ} \mathrm{C}$ 亿加熱すると発煙分解して銅鏡を 生ずる ${ }^{26)}$ 。

最近のオランダ特許 ${ }^{27}$ では，銅セッケン 60 90\%，力 ドミウムセッケン 40〜10\% よりなる触媒を用い, 加圧 下に不飽和脂肪酸を還元して対応する不飽和アルコール を得ている。実施例を示すと， $15 \mathrm{~g}$ の炭酸銅呿よび $5 \mathrm{~g}$ の酢酸カドミウムを $120^{\circ} \mathrm{C}$ に加熱したオレイン酸に溶 か乙, 水素压 $232 \mathrm{~atm}, 280 \sim 300^{\circ} \mathrm{C}$ で還元を行ない, 高級アルコール収率 89\%，ヨウ素価 75.0 (原料脂肪酸 のヨウ素価 79.6) の結果を得ている。カドミウムセッ ケンを併用しない場合は同条件下でヨウ素価は 5 または それ以下低下する。

同特許では銅就よびカドミウムは反応の初期に微粉末 金属として存在し，このものが触媒作用を呈すると述べ ている点は注目される。もしこれが真実であれば他の金 属セッケンを触媒とする高圧還元る本質的には銅クロマ イト系触媒の場合と同じく異相系反応の取り扱いをする 必要がある。

\section{4. 工業的製造方式について}

高圧還元による高級アルコールの工業的製造方式につ いては，原料，触媒，特よび工程の相異により，現在ま 
でいろいろな方式が考案されてきた。その代表的なるの として,

(i) 蒸留式

(ii) 溢流式

(iii) 生成アルコールの一部を原料脂肪酸とともと反 応筒飞圧入乙て，エステル化とロウエステルの還 元を同一反応筒内で行なう方法 (Deutsche Hydrierwerke 社)。

(iv）生成アルコールと原料脂肪酸とのエステル化と ロウエステルの高圧還元を别装置で行なう方法 (Marchon Products 社)。

（v）脂肪酸低級アルキルエステルを2 種の固定触媒 を使用して，カルボキシル基と不飽和結合の還元 を2段飞行なう方法 (SBA 社 $\rightarrow$ Blaw-Knox 社)。

(vi) 銅クロマイト系触媒による脂肪酸の直接高圧還 元法 (Haward 社, De Nora 法 $\rightarrow$ Lummus 社。 酸水素油脂 (株) )。

（vii）銅セッケンを触媒とする脂肪酸の直接高圧還元 法 (Givaudan 社 $\rightarrow$ Barnebey 社)。

があるがこれらとついては既飞油脂技術講座 ${ }^{6}$ 亿述べて いるので, ここで最近の特許基づいていくらかの補 足を加光ると止市る。

SBA 法汪よる脂肪酸低級アルキルエステルの高圧還 元萔いては, 第 1 反応筒でカルボキシル基を水酸基に 還元し,第 2 反応筒で不飽和結合の飽和を行なうよう, 特 の特の特定の固定触媒が充テンされて和り，この触媒の 着命はきわめて永く,年 $2 \sim 3$ 回の取り換光ですむといわ れていたが，先の内容については不明であった。最近公 告された英国特許 ${ }^{28}$ とよると，第 1 触媒は西鉛・銅ク口 マイトで,酢酸に酸化銅, 西鉛華, 酸化クロムを溶解し, こ れと活性炭を添加してかくはんしながら溶液を蒸発させ て調製する。第 2 触媒はケイ酸ニッケルで,アルカリ性の ケイ酸ナトリウム溶液に硝酸ニッケル溶液を注加してケ イ酸ニッケルを沈降せしめ,充分水洗した後,アスベスト を加光て乾燥させたものである。第 1 触媒は $300 \sim 360^{\circ} \mathrm{C}$ で, 第 2 触媒は $180 \sim 250^{\circ} \mathrm{C}$ で使用して, エステルのア ルコールヘの還元と不飽和結合の飽和を別々と行なう。

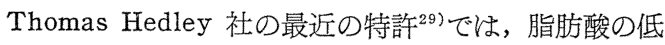
級アルキルエステルを銅クロマイト触媒 1 5\% で，0.3 〜 1.4 モル\%の一酸化炭素を含む水素を使用し，3000 $\mathrm{psi}, 570 \sim 600^{\circ} \mathrm{F}$ で連続還元している。エステルの送入 速度 $140 \sim 1690 \mathrm{lb} / \mathrm{hr}$, 水素: エステル比 $15: 1 \sim 40: 1$ 反応時間 15.3 18.1 min でアルコール変換率 95.3〜 $97.8 \%$, 炭化水素の副生 $0.3 \sim 0.9 \%$ の成績を得ている。

脂肪酸のメチルエステル化, 過剩メタノールと生成水

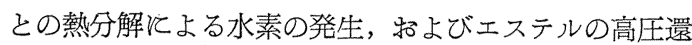
元を同一反応筒で一挙行行なう興味ある考案が SBA 社 ${ }^{30}$ とよりなされた。脂肪酸と過剩のメタノールとを水素
添加触媒の存在下 させる。水素添加触媒としては，銅，西鉛，鉄または酸 化クロムを併用する。過剩使用したメタノールの一部

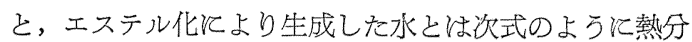
解して活性水素を発生する。

$$
\begin{aligned}
& \mathrm{CH}_{3} \mathrm{OH} \rightarrow \mathrm{CO}+2 \mathrm{H}_{2} \\
& \mathrm{CO}+\mathrm{H}_{2} \mathrm{O} \rightarrow \mathrm{CO}_{2}+\mathrm{H}_{2}(+ \\
& \hline \mathrm{CH}_{3} \mathrm{OH}+\mathrm{H}_{2} \mathrm{O} \rightarrow 3 \mathrm{H}_{2}+\mathrm{CO}_{2}
\end{aligned}
$$

この活性水素により脂肪酸のメチルエステルは容易に還 元されて対応する高級アルコールと変換する。(3) 式の 分解反応は吸熱であるため, 発熱反応である還元の際の 過度の温度上昇を阻止する。回収メタノールは循環使用 することができる。

この方式は非常和るしろい着想であるが, 最適反応 条件の異なるエステル化, “水素の発生, 高圧還元の 3 反 応を同一条件で行なわせているわけで，高級アルコール の大規模生産には，品質括よびコスト両面から必ずしも 適当しているとはい充なようと思われる。

\section{5.むすび}

高圧還元とよる高級アルコールの製造は, ドイツそ特 いて初めて工業化されてから既飞 30 年余, 日本江導入 されてから 23 年を経過してほぼ確立された工業に生長 し, 現在油脂工業の重要な一部門を占めている。最近に 招いては本質的な進歩は少ないが，経済性を考虑して生 産技術の面では種々の改良, 発展が着実行なるれてい る模様で，な特一層の発展が期待される。

\section{（昭和 34 年 5 月 12 日受理） \\ 文献}

1) V.L. Hansley, Ind. Eng. Chem., 39, 55 (1947)

2) Chem. Eng. News, $46(1958,1,27)$; Ind. Eng. Chem., 51, 13 (1959)

3) Oil, Paint \& Drug Reptr., 3 (1958.9.22)

4) Chem. Trade J., $1139(1958,11,14)$

5) 小森, 豊田, 本誌, 3, 84 (1954)

6) 宮川, 油脂技術講座, 109 (1956)

7) H. Adkins, J. Am. Chem. Soc., 70, 4174(1948)

8) O.A. Hougen, K.M. Watson, "Chemical Process Principles," Vol.III (1947), Wiley, New York.

9) I.A. Eldib, L.F. Albright, Ind. Eng. Chem., 49, 825 (1957)

10) R.H. Price, D.B. Schiewetz, ibid., 49, 807 (1957)

11）宫川，油脂技術講座，113（1956）

12) H. Adkins, R. Connor, J. Am. Chem. Soc., 53, 1091 (1931)

13) H. Adkins, K. Folkers, ibid., 53, 1095 (1931)

14) K. Folkers, H. Adkins, ibid., 54, 1145(1932)

15) G. Calingaert, G. Edgar, Ind. Eng. Chem., 26, 878 (1934)

16) T.W. Riener, J. Am. Chem. Soc., 71, 1130 (1949)

17) H. Adkins, E.E. Burgoyne, H.J. Schneider, ibid., 72, 2626 (1950) 
18) J.M. Church, M.A. Abdel-Gelil, Ind. Eng, Chem., 49, 813 (1957)

19) J.D. Stroupe, J. Am. Chem. Soc., 71, 569 (1949)

20) J.G. Kane, K.B. Kulkarni, J. Sci. Ind. Research (India), $13 \mathrm{~B}, 890$ (1954) [C.A., 49, 14345 (1955)]

21) J.G. Kane, K.B. Kulkarni, J. Proc. Oil Technologists' Assoc., India, Kanpur, 10, 43 (1954) [C.A., 51, 11736 (1957)]

22) K. Lauer, O. Paner, B.D. Aly Gebril, Österr. Chem. Ztg., 56, 225 (1955) [C.A., 50, 9763 (1956)]

23) J.M.M. Moreno, R.E. Torregrosa, A.V. Roncero, Grasas y aceites (Seville, Spain), g,
60 (1958) [C.A., 53, 1104 (1959)]

24) 小森, 工化, 41, 419 (1938)， 42, 501 (1939), 43, 52, 748, 910 (1940)

25) Deutsche Hydrierwerke A.-G., Brit., 396,311 (1933) [C.A., 28, 669 (1934)]

26）上野, 小松, 工化, 41, 108 (1934)

27) N.V. Olieraffinaderij “Zuilen", Dutch 83, 379 (1956) [C.A. 52, 3373 (1958)]

28) Société Belge de l'Azote et des Produits Chimiques du Marly, Brit., 795,573 (1958) [C. A., 53, 743 (1959)]

29) Thomas Hedley \& Co., Ltd., Brit., 783, 661 (1957) [C.A., 52, 4216 (1958)]

30) Société Belge de l'Azote et des Produits Chimiques du Marly, U.S., 2,844,633 (1957)

\title{
金属ナトリウムによる油脂およびェステルの還元
}

\author{
福 島 正 敏“ \\ Reduction of Fats, Oils and Esters with Metallic Sodium
}

Masatoshi Fukushima

油脂あるいは脂肪酸エステルを金属ナトリウムを用い て還元し, 第一アルコールを合成する方法は 1903 年に Bouveault et Blanc 飞よって発見され ${ }^{1,2)}$, 実験室飞 祘いて高級アルコールを製取する一般的な方法としてと り上げられ, 天然油脂の成分研究, 硫酸エステルを初め とする種々の誘導体の研究に利用されてきたが, 反応方 式自体にいるいるな改良は行なわれたにかかわらず，高 級アルコールの収率改善の決定的な方法は容易に見出し 得なかった。一方 Bertsch ${ }^{3}$ による高級アルコール 硫 酸エステルの研究は古くから行なわれてきた硫酸化油の 分野に新製品提供の可能性を示し，今日の合成洗剂発展 の端緒をつくったが，このときと前後して高級アルコー ルを工業的に製造するための研究が盛んとなり，ドイッ 飞抬いて 1928 年高圧還元法の最初の工場が建設された。

思うに高級アルコールの製造法として高圧還元が最初 に工業化されたのは当時の化学工業界の案情から考えれ ば当然であり，この結果，金属ナトリウムによる還元法 は央験室的な方法として重用されたにとどまった。

しかしながら一方過酸化ナトリウム，シアン化ナトリ ウムなどの金属ナトリウムを使用する工業薬品の登場 そよって，金属ナトリウムの生産コストは低下し，特に アメリカに和いて Downs とよる融解塩電解が実施され たことはこの傾向に拍車をかけ, Bouveault et Blanc 法の工業化が真剣に検討された結果, Hansley $5^{4), 5)}$ よって高級アルコールの収率改善の研究が成功し，1942 年金属ナトリウムによる高級アルコールが初めて工業的

\footnotetext{
*日本曹達株式会社二本木工場（新潟県中頸城郡）
}

そ製造された。わが国ではやや遅れ，1957 年にその生 産が開始された。

金属ナトリウム還元法と高圧還元法の基本的な違いは 二重結合に対する反応であり，前者の方法では一部の共 役二重結合を除いては水素添加を受けることはない。こ のため原料の選択によって各種の不飽和高級アルコール を製取しろることになる。したがって Bouveault et Blanc 還元の工業化によってリノールアルコール 以上 の高度不飽和アルコールの生産も可能となり, 塗料, 潤 滑油添加剤, 可塑剤などへの今後の利用開発に希望を与 えていることは御同慶とたえない。

金属ナトリウムによる還元は油脂工業の面からみた場 合，高級アルコールの製造と利用がその中心となること は, 今日の経済的背景からやをを党ないが; Bouveault et Blanc 還元の基本となるカルボキシル基へのナトリ ウムの付加反応のほか， $九$-水素のプロトン化などの反応 も行ないろるので，原料と反応条件によってはいろいら と異なった生成物が得られる。たと党ばカルボニル化合 物，ハロゲン化アルキルなどをエステルとともに還元す るときは反応生成物にかなりの変化を与えることがで き, 化学的飞る興味がある。油脂工業の分野で現在利用 されているものは高級アルコール以外は少なく, 今後の 研究の発展に期待するところが多いので, この観点から 遂次解説を試みることにした。

\section{1. 金属ナトリウムの性質}

金属ナトリウムは $\mathrm{mp} 97.7^{\circ} \mathrm{C}$ のやわらかい金属であ り， $100^{\circ} \mathrm{C}$ 以上の反応飞和いては容易に液体となる。ま 